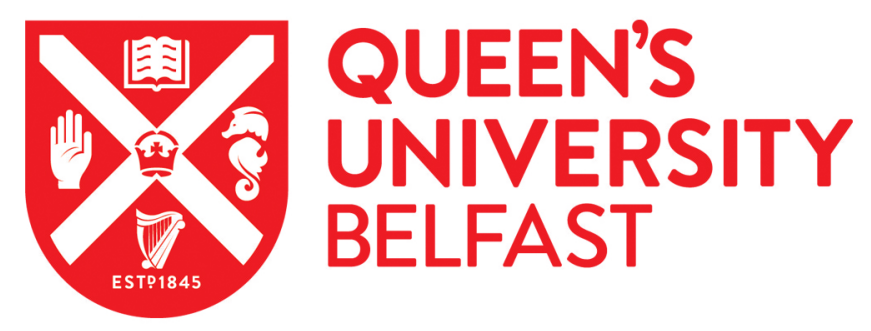

\title{
Worsening Child Outcomes? Caregiver Imprisonment and Its Impact on Child Poverty, Health, Wellbeing and Education in Uganda
}

Butler, M., \& Misinde, C. (2020). Worsening Child Outcomes? Caregiver Imprisonment and Its Impact on Child Poverty, Health, Wellbeing and Education in Uganda. European Journal on Criminal Policy and Research, 27(4), 533-551. https://doi.org/10.1007/s10610-020-09440-9

Published in:

European Journal on Criminal Policy and Research

Document Version:

Publisher's PDF, also known as Version of record

Queen's University Belfast - Research Portal:

Link to publication record in Queen's University Belfast Research Portal

Publisher rights

Copyright 2020 the authors.

This is an open access article published under a Creative Commons Attribution License (https://creativecommons.org/licenses/by/4.0/), which permits unrestricted use, distribution and reproduction in any medium, provided the author and source are cited.

\section{General rights}

Copyright for the publications made accessible via the Queen's University Belfast Research Portal is retained by the author(s) and / or other copyright owners and it is a condition of accessing these publications that users recognise and abide by the legal requirements associated with these rights.

Take down policy

The Research Portal is Queen's institutional repository that provides access to Queen's research output. Every effort has been made to ensure that content in the Research Portal does not infringe any person's rights, or applicable UK laws. If you discover content in the Research Portal that you believe breaches copyright or violates any law, please contact openaccess@qub.ac.uk. 


\title{
Worsening Child Outcomes? Caregiver Imprisonment and Its Impact on Child Poverty, Health, Well-being and Education in Uganda
}

\author{
Michelle Butler ${ }^{1}$ (D) Cyprian Misinde ${ }^{2}$
}

Published online: 14 July 2020

(C) The Author(s) 2020

\begin{abstract}
Increasingly, research investigates how the imprisonment of those with child care responsibilities may affect children and their outcomes. However, this research is often conducted in high-income, developed countries, with little known about its impact in lowincome, least developed countries. This study starts to address this gap by examining if the imprisonment of those with child care responsibilities in Uganda, a low-income least developed country, may affect child poverty, wellbeing, health, diet, and education. Drawing on 76 interviews conducted with 61 adults and 15 children, participants were asked to recount what affect, if any, imprisonment of the child's caregiver was believed to have on child poverty, health, wellbeing, diet, and education. The findings reveal that imprisonment was believed to have a largely negative effect on these aspects of children's lives for most children, hindering government efforts to improve child outcomes and tackle key development challenges. Based on these findings, it is argued that our theoretical understanding of imprisonment and its effects may need to be broadened to include how differing socio-economic policy contexts may moderate the impact of imprisonment on child outcomes.
\end{abstract}

Keywords Children · Parental imprisonment · Effects of imprisonment · Uganda · Incarceration

Michelle Butler

michelle.butler@qub.ac.uk

Cyprian Misinde

cmisinde@gmail.com

1 School of Social Sciences, Education and Social Work, Queen's University Belfast, Belfast, Northern Ireland

2 Department of Population Studies, School of Statistics and Planning, College of Business and Management Science, Makerere University, Kampala, Uganda 
Recent years have witnessed a growing interest in how the imprisonment of parents and family members may affect children (Flynn and Eriksson 2015; Foster and Hagan 2009; Hagan and Foster 2012; Murray 2005; Wildeman 2014). However, most of this research has taken place in high-income, developed countries, especially in Europe, UK, the USA and Australia (Besemer and Dennison 2018; Flynn and Eriksson 2015; Hagan and Foster 2012; Murray 2005; Wildeman 2014). Less is known about how parental imprisonment and the imprisonment of family members with child care responsibilities in low-income, least developed countries may affect children. This is despite research suggesting that the effects of parental imprisonment can vary between jurisdictions (Besemer et al. 2011; Murray et al. 2007). Lowincome, least developed countries are countries that have very high levels of poverty and low levels of human resources, and are vulnerable to economic and environmental shocks (UNCTAD 2019). Improving child outcomes is often one of the key development challenges that low-income, least developed countries face, as they struggle to deal with early school leaving, poor educational attainment, insecure youth employment, child poverty, hunger, ill health and reduced well-being (McCoy et al. 2016; UNICEF 2016; UN 2018). Many lowincome, least developed countries imprison large numbers of people on pre-trial detention, with these individuals often being parents due to high birth rates (ICPR 2019; World Bank 2019). Yet, how the imprisonment of those with child care responsibilities may affect children and the ability of governments to tackle key development challenges, such as inequality, child poverty, hunger, early school leaving, ill health and reduced well-being, has not been considered.

This paper begins to address this gap in knowledge in three ways. Firstly, it provides exploratory qualitative findings into how the imprisonment of those with child care responsibilities are believed to affect children in Uganda, a low-income, least developed country. Secondly, based on the findings, how the imprisonment of those with child care responsibilities may hinder efforts to tackle development challenges, such as child poverty, hunger, ill health, early school leaving, reduced well-being and inequality, are outlined. Thirdly, by comparing the effects of caregiver imprisonment in a low-income, least developed country with those in a high-income, developed country, this paper seeks to start a conversation about how our theoretical understanding of caregiver imprisonment may need to be broadened to include how differing socio-economic policy contexts may moderate its impact on children. In this paper, the term caregiver imprisonment is used over parental imprisonment as often children in low-income, least developed countries are looked after not just by their parents but also by grandparents, aunts, uncles and siblings (Beegle et al. 2010). In the next sections, previous studies investigating how caregiver imprisonment may affect children are reviewed, before the methodology employed to conduct the present research is described. Next, the research findings are presented, before the paper concludes with a discussion of the findings and their potential implications.

\section{Effects of Imprisonment on Children}

Four main theoretical perspectives have been used to explain why caregiver imprisonment may affect children. These include the trauma perspective, the strain perspective, the social learning perspective and the labelling and stigmatisation perspective (Hagan and Dinovitzer 1999; Murray and Farrington 2008a). The trauma perspective is based on attachment and social bonding theories and argues that the trauma children experience at being separated from 
their caregiver causes adverse outcomes (Murray and Farrington 2008a). Separation as a result of caregiver imprisonment is believed to be sudden and unexpected, severely restricting the amount of contact between children and their caregivers, resulting in reduced well-being, sadness, separation anxiety and insecure attachments (Bernstein 2005; Murray et al. 2007; Poehlmann 2005). In contrast, the strain perspective proposes that the imprisonment of a caregiver places an economic and child care strain on families and that it is the loss of the economic and child care resources that the imprisoned caregiver contributed to the family that causes the adverse child outcomes (Hagan and Dinovitzer 1999; Murray and Farrington 2008a). For example, caregiver imprisonment may cause adverse outcomes due to a lowering of the family income and a reduction in the quality of care and supervision children receive (Eddy and Reid 2003; Farrington 2003). The social learning perspective hypotheses that children may experience adverse outcomes as the imprisonment of a caregiver may cause them to model their caregiver's criminality (Murray and Farrington 2008a). It is thought that children may become more aware of the criminality of their caregiver following imprisonment and begin to model antisocial behaviour (Murray and Farrington 2008a). According to the labelling and stigmatisation perspective, it is the stigma and labelling that children are exposed to following caregiver imprisonment that causes adverse outcomes (Hagan and Dinovitzer 1999; Murray and Farrington 2008a). Children may be exposed to bullying, teasing, name calling, social exclusion and increased monitoring by state officials as a result of their caregiver's imprisonment, with this stigmatisation and labelling believed to cause the adverse outcomes they subsequently experience (Hagan and Dinovitzer 1999; Murray 2005; Murray and Farrington 2008a).

Evidence can be found for all four theoretical perspectives, however, it is difficult to establish clear causal pathways due to problems in isolating the effects of separation from the effects of strain, stigma or social learning, as well as controlling for the differences that may already exist between these families and those who do not experience imprisonment (Hagan and Dinovitzer 1999; Murray and Farrington 2008a). These theoretical perspectives tend to focus on the characteristics of the caregiver and child, the caregiver-child relationship, family context and/or immediate environmental factors affecting the child/family, with less attention paid to how differing socio-economic policy contexts may moderate the impact of caregiver imprisonment on child outcomes.

Studies in high-income, developed countries have found that caregiver imprisonment can have predominately negative effects on children (Flynn and Eriksson 2015; Foster and Hagan 2009; Hagan and Foster 2012; Wildeman 2014). For instance, caregiver imprisonment has been found to contribute to financial hardship, social exclusion, relationship breakdown and reduced well-being, as well as increasing the risks of children becoming involved in crime and/ or imprisoned later in life (Butler et al. 2015; Murray 2005, Murray and Farrington 2008a, 2008b; Kjellstrand and Eddy 2011; Jones and Wainaina-Woźna 2013; Wildeman 2014). Additionally, in comparison with other types of separation, caregiver imprisonment has been found to predict antisocial behaviour, delinquency, anxiety and depression in adulthood, even when parental criminality and other childhood risk factors are controlled for (Murray and Farrington 2008a, 2008b). Yet, studies in high-income, developed countries have also highlighted contradictory findings with regard to the extent to which caregiver imprisonment can affect children, with different findings emerging depending on the jurisdiction, gender of the children and extent to which the imprisoned caregiver was a positive and involved figure in the children's lives (Besemer et al. 2011; Besemer et al. 2018; Gaston 2016; Geller et al. 2012; Murray et al. 2012; Murray et al. 2007; Turney and Wildeman 2015). 
For children who report positive relationships with their caregiver, imprisonment can result in children experiencing financial hardship, poorer educational attainment, social exclusion, criminality, anger, reduced well-being and worsening health, as well as mental health and behavioural problems (Andersen 2016; Foster and Hagan 2009; Mears and Siennick 2016; Miller and Barnes 2015; Murray 2005; Wakefield and Wildeman 2013; Wildeman 2014; Wildeman et al. 2018). However, for those who report negative, violent or abusive relationships, imprisonment can be beneficial and improve child outcomes (Amato et al. 1995; Gaston 2016; Geller et al. 2012; Wildeman 2014). Other effects of caregiver imprisonment found in high-income, developed countries include children experiencing separation anxiety, behavioural disturbances, worry about the safety and well-being of their imprisoned caregiver and a decrease in stable, quality parenting due to the absence of their imprisoned caregiver and additional work commitments taken on by the adult(s) looking after them in the community (Butler et al. 2015; Jones and Wainaina-Woźna 2013; Murray 2005). When mothers are imprisoned, the potential impact of caregiver imprisonment is believed to be even greater as often children can be placed into care, if others are unable to assume responsibility for the children's welfare (Dallaire 2007). Furthermore, research in the USA indicates that caregiver imprisonment can contribute to racial disparities in child homelessness and black-white inequalities in civil and political participation, as the effects of familial economic hardship following imprisonment were more concentrated among African Americans, with African Americans also experiencing decreased access to institutional support (Wildeman 2014). It is, therefore, important to consider how caregiver imprisonment may affect children.

\section{The Present Study}

This study seeks to enhance our understanding of caregiver imprisonment on children by examining how caregiver imprisonment in Uganda, a low-income least developed country, was experienced by children and the adults looking after these children in the community. In Uganda, concerns have been expressed about the number of people imprisoned and the nature of the offences they have been imprisoned for (Foundation for Human Rights Initiative 2015; Office of the Auditor General Uganda 2016; Uganda Bureau of Statistics 2017; Republic of Uganda 2015). Most people in prison are male, aged under 34 and imprisoned for burglary, theft, murder and aggravated defilement (Uganda Bureau of Statistics 2017). A shortage of judicial officers, corruption and a lack of alternatives to imprisonment have resulted in large numbers of people being imprisoned for predominately minor offences (especially burglary and theft), with these individuals often waiting long periods of time for their case to be heard in the courts (Foundation for Human Rights Initiative 2015; Office of the Auditor General Uganda 2016; Republic of Uganda 2015). Over half of the prison population (51\%) is on pre-trial detention, meaning that these individuals have not yet been found guilty of an offence, with $34 \%$ waiting more than 2 years to have their case heard in the courts due to the shortage of judicial officers (ICPR 2019; Office of the Auditor General Uganda 2016). The lack of alternatives to custody has also meant that the courts have few options other than imprisonment at their disposal, especially if those found guilty of an offence lack the funds to pay a fine (Republic of Uganda 2015). Moreover, corruption is an issue as many people can evade arrest, prosecution and imprisonment if they can afford to bribe criminal justice officials (Foundation for Human Rights Initiative 2015; Republic of Uganda 2015). The Ugandan government has acknowledged that corruption and the lack of court-appointed solicitors are resulting in a 
prison population in which poorer people are over-represented, further contributing to poverty and inequality in society (Republic of Uganda 2015). While the Government of Uganda accepts that there is a need to reform the criminal justice system to tackle corruption and provide a more efficient and effective criminal justice system, it has not yet considered how the imprisonment of caregivers may affect children and the outcomes they experience (Republic of Uganda 2015).

Child poverty, hunger, malnutrition, poor educational attainment, early school leaving and reduced well-being are common in Uganda and the Ugandan Government views tackling these challenges as essential for the development of a stronger economy (Republic of Uganda 2015; Uganda Bureau of Statistics 2017). Gender norms in Uganda also encourage men to be the main financial providers for their children, contributing to gender disparities in pay, employment and land ownership (Republic of Uganda 2007, 2015). Additionally, Uganda has one of the youngest populations in the world, with a fertility rate of 5.4 children (Republic of Uganda 2007, 2015; Uganda Bureau of Statistics 2017). Nevertheless, how the unnecessary use of imprisonment for predominately minor property-related offences may affect the children and families of those imprisoned - especially as it is mainly men who are imprisoned, with these men expected to financially provide for their families - has not been previously studied (Republic of Uganda 2015).

This paper seeks to examine how caregiver imprisonment was experienced by children and the adults looking after these children in Uganda, to investigate if they believed the imprisonment of a caregiver influenced the child's health, well-being, education, poverty or diet. More specifically, this paper seeks to answer the following two research questions:

Research question 1: Do children with an imprisoned caregiver in Uganda believe that the imprisonment of their caregiver affected their health, diet, well-being, education or experience of poverty?

Research question 2: Do the adults who are looking after these children in the community in Uganda believe that the imprisonment of a child's caregiver affected the child's health, diet, well-being, education or experience of poverty?

Given the tendency for research in high-income, developed countries to highlight the potential negative impact caregiver imprisonment can have on children, it is hypothesised that both adults and children will report a worsening of child health, diet, well-being, education and poverty following the imprisonment of a caregiver.

\section{Methodology}

A mixed research design, consisting of quantitative (retrospective self-report questionnaire) and qualitative (in-depth semi-structured interview) components, was used to explore caregiver imprisonment in Uganda. This paper focuses on the qualitative component of the research to provide a rich, detailed account of how children and the adults looking after these children experienced caregiver imprisonment and, specifically, to examine if they believed that caregiver imprisonment influenced children's health, well-being, education, diet or experience of poverty. Further information on the retrospective self-report questionnaire and its findings can be found in Butler and Misinde (2018).

In-depth semi-structured interviews are especially useful when seeking to examine participants' experiences and beliefs as they allow a topic to be explored in more detail and with greater freedom than is possible in a questionnaire (Bachman and Schutt 2011). Participants' 
answers can be probed to clarify their meaning and thicker descriptions of social interactions, processes and customs can be obtained (Bachman and Schutt 2011). Additionally, some participants may feel more comfortable sharing their experiences in an interview setting as they begin to develop a rapport with the interviewer (Edwards and Holland 2013). Nonetheless, there are also limitations associated with the use of interviews. For example, depending on the size and representativeness of the sample, there can be limits to the extent to which the findings can be generalised to the wider population (Creswell 2013). Yet, it is because of the strengths of using interviews to explore participants' experiences and beliefs in detail that indepth semi-structured interviews were deemed to be the most appropriate method for answering this study's research questions.

\section{Sample}

A convenience sampling strategy was used to recruit potential participants. As there are no administrative records held of the children affected by imprisonment in Uganda, potential participants were voluntarily recruited by approaching imprisoned caregivers in the Uganda Prisons Service and asking these individuals to provide contact details for their families. Researchers entered three local prisons (Sentema, Kasangati and Mpigi) in the Central region of Uganda to explain the purpose of the study and what participation in the study would involve. Next, the imprisoned caregivers were asked if they were willing to voluntarily consent to allow the researchers to contact their families to ask them to participate in the research. Two key benefits of using this recruitment method included that it allowed the researchers to obtain the consent of the imprisoned caregivers before approaching their families and it ensured that researchers were provided with accurate contact information for the families. The voluntary nature of the research was explained to all and it was stressed that there would be no negative consequences for them, or their families, if they chose not to participate.

One hundred imprisoned caregivers gave their consent for the researchers to contact their families and provided the contact details for 100 families. In order to determine the eligibility of family members to participate in the research, sampling criteria were used. Children were only eligible for inclusion if they met the following criteria:

- Both their imprisoned caregiver and the adult looking after the child in the community had given their consent for the researcher to speak with the child.

- The child had voluntarily given their informed consent to participate in the research.

- The child was aged between 10 and 17 years of age.

- The child had a caregiver imprisoned at the time the research was being conducted.

The following sampling criteria were used for adults, with adults only being eligible to participate if they met these criteria:

- The adult was responsible for looking after a child with an imprisoned caregiver at the time the research was being conducted.

- The adult was aged 18 or over.

- The adult had given their informed voluntary consent to participate in the research. 
Of the 100 families contacted, 61 were willing to be interviewed. Common reasons given for the unwillingness of families to take part in the interviews were a lack of time, a fear that talking about the effects of imprisonment would lead to distress or a desire to avoid taking part in research. When the selection criteria were applied to the adult family members, 61 adults (one adult from each family) were eligible to take part in the interviews. Similarly, when the selection criteria were applied to the children in these families, 15 children were eligible to take part, with two children coming from the same family. More adult participants were included in the sample than children as, drawing on census data, it had been anticipated that each family would have at least three children aged between 10 and 17 years that may be eligible to participate in the research. However, this was not the case as most of the families contacted contained young children aged less than 10 years of age. These young children were ineligible to participate as the interview questions were designed for use with children aged 10 or older. Moreover, in some cases, the adults looking after the children were unwilling to give their consent for the researchers to speak to the children or the children were not available to be interviewed when the researchers visited the families. Reasons given by the adults for their unwillingness to give their consent included that the children were unaware of their caregiver's imprisonment and/or they were concerned that the children would become distressed during the interview. In these situations, the adults looking after the children were willing to be interviewed. Consequently, 76 participants took part in the interviews, consisting of 61 adults and 15 children, drawn from 61 families.

In order to protect the anonymity of participants, only some basic demographic information were collected. Of the 61 families interviewed, the majority reported that the imprisoned caregiver was the children's father $(n=54)$, followed by their mother $(n=6)$ and their uncle $(n=1)$. Among the adult participants, the vast majority were female $(n=55)$, being either the mother of the children $(n=39)$, an aunt $(n=4)$ or a grandmother $(n=12)$, reflecting the tendency within Uganda for child care responsibilities to primarily fall to women (Datzberger and Le Mat 2018; Lundgren et al. 2019). Six adult males were interviewed, consisting of two fathers, three uncles and one male teacher who had assumed responsibility for the child care of children who were left destitute following the imprisonment of their mother. Among the child participants, six were male and nine were female. These children were being looked after by either their mother $(n=11)$ or grandmother $(n=4)$ and ranged in age from 10 to 17 years. All but one of the children knew that their caregiver was imprisoned, with this one child being told that their caregiver had moved to another village to find work. In over a third $(n=24)$ of the families, the children were required to change caregivers as they moved to live with grandmothers, aunts, uncles and a teacher who assumed the child care duties left vacant by the imprisoned caregiver. While most families lived in the Central region where the prisons were located, a few families were scattered across the Eastern, Northern and South-western regions of Uganda.

\section{Procedure}

Data collection was undertaken by a team of trained research assistants from Makerere University over a 3-month period. Informed voluntary consent was obtained from the imprisoned caregiver, the adult looking after the children in the community and the children. Great care was taken to ensure that participants understood the voluntary nature of the research and did not feel coerced to participate. Ethical approval to conduct the research was obtained 
from the Uganda Prisons Service, Makerere University and the Ugandan National Council for Science and Technology, as well as Queen's University Belfast. Only those families for whom the imprisoned caregiver had given their consent to contact were contacted. When contacting the families, the researchers explained who they were, how they had obtained their contact details and the purpose of the research. What was involved in taking part in the research was also explained, as well as its voluntary nature and that there would be no negative consequences for the families, or the imprisoned caregiver, if they chose not to participate.

If participants gave their informed consent, they were asked to complete an interview in which they were asked about their experiences of caregiver imprisonment and whether they believed that the imprisonment of children's caregivers had affected their health, well-being, diet, education or experience of poverty. An interview schedule was used to guide the in-depth semi-structured interviews, with participants being asked to recall their experiences of family life, and children's health, well-being, education, diet and poverty before and after the imprisonment of their caregiver or, in the case of the child unaware of their caregiver's imprisonment, before and after they had left to find work. Adults were asked to consider the possible affect caregiver imprisonment may have had on all children affected by caregiver imprisonment in their care. Children were asked about their own experiences, as well as the experiences of any siblings, as often their siblings were too young to participate in the research or were not at home when the researchers visited the family. Participants were also asked to describe their family relationships with the imprisoned caregiver, caregiving arrangements before and after caregiver imprisonment and the extent to which children visited their imprisoned caregiver. Children were free to choose whether they wanted a family member to accompany them while taking part in the research, with three children requesting a family member to accompany them during the interview. Participants were reminded that they were free to stop participating in the research or refuse to answer a question at any stage, without any explanation or negative consequences. With the permission of participants, interviews were recorded and transcribed for analysis. On completion of the interview, participants were thanked for their time and given the researchers' contact details in case they had any further questions or wished to withdraw from the study.

\section{Data Analysis}

The interview data were transcribed and entered into NVivo for analysis. Thematic analysis was used to analyse the interview transcripts, as thematic analysis is a qualitative methodology used to identify, analyse and report patterns or themes in a qualitative dataset (Braun and Clarke 2006). This method of analysis was chosen due to its flexibility and ability to identify recurring themes in participants' responses. As suggested by Braun and Clarke (2006), the six stages of thematic analysis were followed: researcher familiarisation with/immersion in the data, initial coding, searching for themes, reviewing themes, defining and naming themes and writing up the research findings. This involved the researchers familiarising themselves with the data, generating initial ideas and searching for themes. A top-down analytical strategy was used to inform the searching for themes, as the research questions sought to specifically analyse the participants' beliefs and experiences regarding whether caregiver imprisonment had affected child health, well-being, diet, education or experiences of poverty. Previous research on parental imprisonment and the effects of imprisonment informed the search for themes but the analysis also allowed for new themes to emerge from the data. This is one of the 
advantages of using thematic analysis as it is flexible enough to combine both deductive and inductive coding. Next, the themes were reviewed, defined and named. The findings of the analysis were then written up. Quotes from the interviews have been chosen for inclusion in this paper as they best exemplify the themes being discussed.

\section{Findings}

The findings are presented in five sections: child well-being; child health and diet; child education; child poverty; study limitations. In these sections, the views and experiences of the children and adults are examined to assess whether they believed that children's experiences of health, wellbeing, diet, education and poverty were affected by the imprisonment of their caregiver.

\section{Child Well-being}

In the interviews, approximately half of the adults believed that children's well-being had been negatively affected by the imprisonment of their caregiver, while roughly half of the adults believed that caregiver imprisonment had not affected the children's wellbeing. Only one adult believed that the imprisonment of the child's caregiver had had a positive effect on their well-being. This adult explained that the imprisonment of the children's mother was beneficial due to the emotional and psychological problems the mother had experienced and the negative impact these problems had had on the children's well-being when the mother lived with them:

Because of her mental disturbance, the children are sometimes unsecure. Sometimes she mistreats them, like she will tell you herself. But some people who see them now and before she went to prison say the children look better now. (Participant 29, adult)

Among the adults who did not believe that caregiver imprisonment had affected the children's well-being, two common reasons were given: children were unaware of their caregiver's imprisonment, or the adults looking after the children were able to financially and emotionally provide for their needs. Several adults explained that they had not informed the children of their caregiver's imprisonment to avoid causing them unnecessary distress:

I am still confused and worried about how to tell them because it may affect them

psychologically. I have not yet told them. (Participant 10, adult)

In some cases, children were attending boarding school away from the family home and it had been decided not to tell these children to avoid disrupting their education and causing them distress:

One is in boarding school. [ ....] They are still young to think about such issues.

(Participant 11, adult)

In other cases, adults explained the caregiver's absence by telling the children they had moved to another area to find work and, consequently, these adults did not believe that the children were affected by their caregiver's imprisonment because they were not aware of their imprisonment: 
No, the children [...] don't know anything. They ask 'Mummy, where did Daddy go?' and I tell them he went to the village and they ask 'Which village? Take us to see Daddy'. They don't know what's going on. [...] I am still hiding it from them. (Participant 43, adult)

A few adults explained that they were in the enviable position of having secure, stable employment and, therefore, were able to provide for both the child's emotional and financial needs, as well as afford for the children to visit their imprisoned caregiver if they so wished. Consequently, these adults did not believe that the children's well-being had been negatively affected by the imprisonment of their caregiver:

The children do not ask [about imprisoned father] because they don't lack anything that they want. (Participant 50, adult)

Among the adults who did feel that the children's well-being had been negatively affected by the imprisonment of their caregiver, they believed this was because the children missed the love and affection of their imprisoned caregiver and were worried about how the family would cope without the emotional and financial support provided by the imprisoned caregiver:

Yes, it has affected her because now she no longer stays with him and cannot get everything she used to get when her father was here, like school fees, clothes and all she desired to have. The child also misses her father so much and she is not happy like before. (Participant 48, adult)

Some adults explained that these emotions had begun to affect the children's behaviour. They explained that children had refused to eat, were acting out and were becoming angry:

This 3-year-old can even refuse to eat food and ask me 'Where is father?' [...] he can spend the day crying [...] 'I want father' [...] It hurts them from within [...] deep inside. They are affected and lacking their father. (Participant 59, adult)

Oh yes, there is change [in child]. I really saw it because when he was there, in the morning the older daughter would tell me 'Mummy, go I will make your bed, you can go' $[. .$.$] but now she no longer wants to do anything at home when her father is not$ there. [...] [Relationship is] Not good at all. [...] They [children] have too much anger towards me. (Participant 22, adult)

With regard to the children, all children reported that the absence of their imprisoned caregiver had negatively affected their well-being, including the child who was unaware of their caregiver's imprisonment. The children explained that they missed the love and affection provided by their imprisoned caregiver, were worried about the health of their imprisoned caregiver and/or were fearful about how the absence of their imprisoned caregiver was affecting their family financially:

Myself, I felt bad [when mother was imprisoned] [...] I thought mum would die in prison. (Participant 68, child)

We worry a lot, we no longer eat well like we used to, even at school. He [imprisoned father] would at times help pay for our school fees but now we don't have someone to do that for us. [...] Ever since he went to prison, we are always worried. [...] I am not 
happy. $[\ldots]$ The one, who was taking care of us, is now not here $[\ldots]$ we children in that state cannot afford to take care of ourselves. (Participant 70, child)

The children explained that they felt less safe at home because they were required to spend more time alone, as the adults looking after them took on additional work to help pay rent and school fees, as well as buy food and medication:

Child: Sometimes I would sleep alone [...].

Interviewer: Were you scared to sleep alone in the house?

Child: Yes, I was. (Participant 68, child)

Accordingly, while nearly half of the adults did not believe that caregiver imprisonment had affected the children's well-being, all children and nearly half of the adults believed caregiver imprisonment had reduced the children's well-being. Only one adult believed that caregiver imprisonment had enhanced child well-being.

\section{Child Health and Diet}

When asked about child health, the majority of adults felt that caregiver imprisonment had negatively affected the children's health, blaming a reduction in the family's finances for restricting the amount of money available to travel to healthcare facilities or pay for healthcare and medication:

I have no money for medicine. [...] The hospital is far [away], it requires a Boda Boda [motorcycle] [to travel there] and I even don't have the fares for the Boda Boda. [...] I see my children might die under my watch because of the situation. I therefore need assistance. (Participant 16, adult)

Adults also believed that children were more likely to become sick because less attention was being made to food preparation and the purification of water. This was thought to be especially likely to occur in cases of maternal imprisonment:

Their mother not being around [due to her imprisonment] used to monitor them fully to know what to eat, drink, where to sleep to prevent diseases like typhoid. It's hard for me so they get sick. [...] They eat enough from my gardens but I have no time to monitor how food is prepared [...] that's why [my] children always suffer from typhoid. (Participant 10, adult)

All but one of the children felt that their health had been negatively affected by the imprisonment of their caregiver. They explained that they frequently became sick due to the stress and worry they felt as a result of the imprisonment of their caregiver, the lack of money to buy food and medication since their caregiver's imprisonment and/or because of the additional chores they were required to undertake to help raise money for the family following their caregiver's imprisonment:

Interviewer: Did you ever fall sick when Daddy was in prison?

Child: Yes.

Interviewer: What do you think was the cause of that sickness?

Child: Stress. We had a lot of stress. Most of us fell sick. (Participant 65, child) 
We suffered with planting tomatoes and spraying them which involves carrying it [spray] on our backs, carrying them [tomatoes] to where to sell them and looking for market. [...] No, we used not to do anything [before father was imprisoned] [...] When he left, we started doing everything ourselves. [...] Our hands would ache, we got headaches and fever. (Participant 67, child)

The one child who did not believe their health had worsened following the imprisonment of their caregiver explained that while they had fallen sick after the imprisonment of their caregiver, a nearby healthcare facility provided free healthcare and medication, helping minimise the possible impact of caregiver imprisonment on their health:

Child: I and another brother fell sick. [...] We went to a health facility and got medicine. Interviewer: Was the medicine free of charge?

Child: Yes, it is a government hospital. (Participant 76, child)

While some healthcare facilities provided free services in Uganda, most of the participants were unable to access these services due to their restricted geographical availability, inability to afford to travel to these facilities and the limited supplies of free medication available. As a result, most participants reported having to pay to access healthcare services and medication.

Among the adults who did not believe that caregiver imprisonment had affected the children's health, they explained that either the children had not become sick following the imprisonment of their caregiver or the children continued to have access to healthcare services, medication and food:

The young one fell sick but I just bought tablets and I treated him and he got better. (Participant 47, adult)

In paying for healthcare services and medication, participants frequently recounted stories of borrowing money or restricting the purchase of food and possessions in order to pay for these services:

There are no drugs at the government health centre so I give the herbal medicine from the nearby bushes or if it gets worse, I get credit [borrow] to take them to [private healthcare] clinic." (Participant 7, adult)

Most adults felt that the imprisonment of the children's caregiver had negatively impacted the children's access to food. They explained that in most cases, it was the children's father who was imprisoned, and, as he had been the main financial provider for the family, the money available to buy food had reduced. Access to food was also often restricted to pay rent, medical bills and school fees to avoid homelessness, severe illness and/or children being excluded from school due to the non-payment of school fees:

[Before father's imprisonment] He used to send money to take care of his family like buying food and [paying] school fees. [...] We were eating well. [...] He used to take care of his family by fulfilling his responsibility as a man. [...] [After imprisonment] Many children dropped out of school and food became a problem. [...] We used to have enough food, eating three meals a day. [...] [Now] We eat one meal a day. (Participant 6, adult)

Similar accounts were told by the children in their interviews. Most children stated they ate less frequently and well after caregiver imprisonment, compared with before their imprisonment, contributing to increased feelings of hunger: 
We would eat everything we wanted when he [father] was around, but when he went to prison, we started eating [only] one meal. (Participant 70, child)

These feelings of hunger were believed to negatively affect children's educational performance, as well as their health and well-being:

I don't know if they will perform well because they come back [from school] when they are hungry. [...] I don't have money to pay for their lunch at school. [...] They were performing well but now the situation [has changed] because children cannot learn when they have not eaten. (Participant 40, adult)

Only a small number of children and adults did not believe that the children's diet had deteriorated following the imprisonment of their caregiver. These participants reported three reasons for this belief: (1) the secure, stable employment of the adults looking after the children in the community allowed them to purchase enough food for the children; (2) family, friends or NGOs donated food to feed the children; or (3) additional work was undertaken by adults and the children to obtain food. Almost half of the adults and most of the children reported taking on additional work following the imprisonment of their caregiver. Nonetheless, many still reported having insufficient funds available, resulting in the family food intake being reduced to pay other bills, such as rent or school fees:

You dig someone's garden first [for money], then you plan what to eat. [...] The eating had to reduce because if I don't pay the rent, the landlord will put us out so you have to save some money for him. (Participant 57, adult)

\section{Child Education}

When discussing the children's education, most of the children stated that their caregiver's imprisonment had hindered their educational performance and attainment. Only one child reported an improvement in their school performance, as they sought to make their imprisoned caregiver proud of their accomplishments. The remaining few children did not believe that caregiver imprisonment had affected their educational attainment or performance as their school fees had been paid and their educational performance was comparable with that of before their caregiver's imprisonment. The majority of adults believed that the children's educational attainment and performance had been negatively affected by the imprisonment of their caregiver. For both adults and children, the main explanation given for this negative impact was the financial difficulties families encountered following the imprisonment of a caregiver. They explained that they had less money available to pay school feels and buy books, uniforms and other scholastic materials, as well as food, with the result that the children's ability to attend school, concentrate and perform well in class was restricted:

No, they [children] don't go to school. [...] I don't have the capacity. I am not working [...] so I cannot afford school fees and other scholastic materials. The father used to provide for them but he is now not here [due to his imprisonment] so my hands are tied. (Participant 17, adult)

We worry a lot [after father's imprisonment] [...] he would at times help pay for our school fees but now we don't have someone to do that for us. [...] Sometimes we miss 
[school], even beginning of [this] term we missed some days, and then last term we also

did not do the exams. (Participant 70, child)

Despite the best efforts of the non-imprisoned adult caregivers to take on extra work, borrow money, defer payments or organise a school bursary/sponsorship for the children, children were often sent home from school due to the non-payment of fees and were not allowed to take part in school examinations until school fees were paid:

I used to enjoy school but when money became a problem, it was always me to be sent back for [not paying school] fees and I would always miss doing exams [...] because of the situation. (Participant 72, child)

The financial hardship experienced by the family following the imprisonment of a caregiver led some children to discontinue their education completely, increasing early school leaving. Adults also explained that they had little free time available to help children with their homework, due to the additional work they had taken on, further contributing to a deterioration in the children's educational performance and attainment. Consequently, only those who could afford to pay school fees, buy scholastic materials, purchase food or obtain a deferment of school fees/school bursary/ sponsorship reported children's education being unaffected by the imprisonment of their caregiver.

\section{Child Poverty}

In asking participants if they believed that caregiver imprisonment had affected the children's experiences of poverty, almost half of the children and most adults believed caregiver imprisonment had exacerbated child poverty, by negatively affecting the family's finances and enhancing the deprivations children experienced. Participants described how caregiver imprisonment worsened the family's financial status due to the loss of income provided by the imprisoned caregiver, the costs associated with their imprisonment (e.g. visiting the prison, paying their bail, fines, legal representation, etc.) and the additional debts amounted as families borrowed money to survive:

It [imprisonment] affected us so much since I [mother] had no income, I resorted to getting loans. [...] The family could not meet its basic needs. (Participant 3, adult)

Often families were forced to reduce their expenditure, sell their possessions and borrow money as they attempted to survive. If the imprisoned caregiver had a business, the stigma associated with imprisonment could negatively affect the income from the business:

His work was antagonised. [...] It has not [...] recuperated yet due to his image being tainted. So, everyone fears to come for service calling him a thief and a fraudster. (Participant 15, adult)

Few families received support from government officials and/or NGOs, with only six participants being offered such help. The male teacher who had assumed responsibility for the children left destitute following the imprisonment of their mother explained he did so because their mother was a member of his church and the church donated food, money and possessions to help meet the children's needs:

She [mother] is our church member. [...] What we did as a church was to think of what we could do. [...] She doesn't have relatives. [...] We said [...] we should look after the 
children. [...] We had to mobilise resources [...] that's what we basically did as a church. (Participant 29, adult)

Family and friends attempted to help the children by providing food, money and child care but often these individuals were poor and could not afford to provide much assistance. Indeed, in some cases, family members exacerbated their own poverty while attempting to help:

I took over [child care] but I cannot manage them well because I also have a big family. [...] I am struggling a lot to look after the two families. [...] Now we cannot afford to eat enough food. (Participant 14, adult)

Siblings were also sometimes separated to share the costs associated with providing for the children's needs if no one family member could afford to look after them all:

Adult: The family separated. Some children went with their mother and others remained with me $[\ldots]$.

Interviewer: Has the imprisonment of [father] affected the money available to the family?

Adult: It has a lot and that's why we had to share the children. [...] Separating the children helped them to get enough care. (Participant 12, adult)

Corruption within the Ugandan criminal justice system was also felt by participants to compound experiences of poverty and inequality, as this corruption meant that those who were the poorest were often imprisoned, as they lacked the funds needed to pay for legal representation, fines, bail and/or bribes:

There is too much corruption everywhere, in police and too much in court. They are after money; you have the money then you win the case. (Participant 23, adult)

In this way, it seemed that caregiver imprisonment could potentially contribute to intergenerational poverty and inequality by exacerbating the poverty that poor families were already experiencing, worsening their finances and ability to meet the health, diet and educational needs of children.

\section{Study Limitations}

While reading these findings, there are limitations which limit the conclusions that can be drawn. For example, the research was based on a small, self-selected, retrospective, cross-sectional sample from one low-income country. This limits the representativeness of the sample, the generalisability of the findings, the identification of changes over time or the ability to make causal predictions. The findings are also based on participants' recollections which may not accurately reflect their reality and cannot be used to prove the mechanisms that may be causing these outcomes. The children's caregivers had been imprisoned between 1 month and 3 years so differences in memory may be evident. Moreover, the full range of children's experiences may not have been captured as children under 10 were not included in the research, as well as children who were not at home or for whom adult consent was not obtained. Additionally, this study only captured limited demographic information about the participants. It is important that future research should collect additional demographic information and address the above shortcomings. Nevertheless, this study offers some interesting exploratory insights into an underexplored topic that warrants further investigation. 


\section{Conclusion}

In answering the research questions, all children interviewed believed their well-being was negatively affected by caregiver imprisonment and all but one (who had access to free healthcare and medication) felt their health had worsened. Most children believed their diet and education were negatively affected by caregiver imprisonment and almost half felt their experience of poverty had worsened. In contrast, adults were more divided in their views on the effect caregiver imprisonment had on child well-being. Almost half believed child well-being was negatively affected, while almost half believed child well-being was not affected. However, like the children, the majority of adults believed caregiver imprisonment negatively affected children's health, diet and education. Most adults also believed that children's experiences of poverty worsened following the imprisonment of their caregiver. Participants' explanations for these beliefs tended to align with the trauma and strain theoretical perspectives (see Hagan and Dinovitzer 1999; Murray and Farrington 2008a). Like previous research in high-income, developed countries, when participants felt that caregiver imprisonment had a negative effect on children, they generally attributed it to the trauma children experienced at being separated from their imprisoned caregiver or the economic strain felt due to the loss of income the imprisoned caregiver provided (Foster and Hagan 2009; Mears and Siennick 2016; Murray 2005; Murray and Farrington 2008a; Jones and Wainaina-Woźna 2013; Wildeman 2014). When they did not believe that caregiver imprisonment had a negative effect, they attributed this to children not being aware of or experiencing trauma/economic strain as a result of their caregiver's imprisonment. As in past studies, if children had a positive relationship with their imprisoned caregiver and their imprisoned caregiver contributed financially to the family, their imprisonment was believed to have a negative effect on the children's lives (Hagan and Dinovitzer 1999; Foster and Hagan 2009; Murray 2005; Murray and Farrington 2008a). In this way, this research begins to shed light on how the imprisonment of those with child care responsibilities in a low-income, least developed country has the potential to negatively affect children's outcomes through the trauma and strain they experience as a result of this imprisonment, similar to the effect of caregiver imprisonment in high-income, developed countries.

Yet, these findings also offer new insights by demonstrating how the effects of caregiver imprisonment may vary depending on the differing socio-economic policy contexts of countries. Like previous studies, these findings demonstrate how caregiver imprisonment can negatively affect children. However, the potential impact of this effect appeared to be greater in the Ugandan context due to the limited availability of free education, healthcare and social welfare services to support these children. The limited availability of these services meant that the potential effects of caregiver imprisonment were not softened by the provision of these services, as they may have been in a high-income, developed country. For example, in many high-income, developed countries (though not all), free education and healthcare services are available, limiting the potential for early school leaving and ill health (arising from a lack of access to medical treatment) to occur due to the financial hardship families may experience following the imprisonment of a caregiver (UNESCO 2019; World Population Review 2019). Children in Uganda appeared to be more vulnerable to experiencing hunger, illness, poverty and early school leaving, as a consequence of caregiver imprisonment, due to the limited provision of these services. In this way, differing socio-economic policies may play an important role in moderating the impact of caregiver imprisonment on children and the outcomes they experience.

For instance, $77.7 \%$ of Ugandan youth are undereducated as their level of educational attainment is to primary school or less (Uganda Bureau of Statistics 2015). The main reason given for why 
children leave school early is because they can no longer afford to pay school fees (Uganda Bureau of Statistics 2015). Based on the participants' accounts, caregiver imprisonment reduced the ability of families to pay school fees, contributing to early school leaving. Similarly, the financial hardship experienced by the families following caregiver imprisonment reduced well-being and increased ill health and hunger, as the ability of families to meet the needs of children and pay for food, healthcare and medication was decreased. When participants were able to obtain school bursaries/sponsorship or free healthcare, they reported that the impact of caregiver imprisonment was lessened. Future research is needed to investigate this issue further to assess if our theoretical understanding of caregiver imprisonment needs to be broadened to include how differing socio-economic policy contexts may affect the impact of caregiver imprisonment on children and their outcomes.

The tendency for poor families to be over-represented in the prison system in Uganda and the lack of support for these families from government officials or NGOs may therefore contribute to intergenerational poverty, vulnerability and inequality, as some of the children from these poor families become poorer, as a result of their caregiver's imprisonment and lack of support they received to combat the potential negative effects of imprisonment. Consequently, the unnecessary imprisonment of caregivers may hinder efforts to improve child outcomes and tackle key development challenges, such as inequality, poverty, hunger, early school leaving, reduced well-being and ill health.

Finally, some thoughts on the possible actions that can be taken to improve the situation of children with imprisoned caregivers in Uganda are offered. To begin with, these children need to be recognised within government policy as a vulnerable group requiring support. The Ugandan Government needs to include children affected by imprisonment as a vulnerable group within their Orphaned and Vulnerable Children's policy and then provide services and supports to assist them. However, it is important that the views of these children are given due consideration by policymakers and practitioners when deciding policy and service provision to ensure their rights are respected and services and supports are designed to best meet their needs. Too often, children's voices are absent from policy and practice discourses within this area, in contravention to their rights under the UN Convention of the Rights of the Child. Other actions that would be beneficial include tackling corruption with the criminal justice system and reducing the over-representation of poor people within the prison system. The use of pretrial detention should be minimised and more judicial officers employed to reduce lengthy waiting times to hear cases within the Ugandan courts. More alternatives to imprisonment should be introduced and government officials and NGOs should be trained to recognise the impact of caregiver imprisonment on children so they can act to help lessen the vulnerability of these children being increased due to the imprisonment of their caregivers. More comparative studies also need to be conducted to enhance our understanding of how the effects of caregiver imprisonment may differ between jurisdictions and identify the reasons for these differences.

Funding Information This research was funded by the Northern Ireland Department for the Economy [R3864SES].

\section{Compliance with Ethical Standards}

Ethical Approval Ethical approval to conduct the research was obtained from the Uganda Prisons Service, Makerere University, the Ugandan National Council for Science and Technologyand Queen's University Belfast. Informed consent was obtained from all participants and the consent of imprisoned caregivers and adults looking after the children in the community was obtained before approaching children to ask for their informed consent to participate in the research. 
Open Access This article is licensed under a Creative Commons Attribution 4.0 International License, which permits use, sharing, adaptation, distribution and reproduction in any medium or format, as long as you give appropriate credit to the original author(s) and the source, provide a link to the Creative Commons licence, and indicate if changes were made. The images or other third party material in this article are included in the article's Creative Commons licence, unless indicated otherwise in a credit line to the material. If material is not included in the article's Creative Commons licence and your intended use is not permitted by statutory regulation or exceeds the permitted use, you will need to obtain permission directly from the copyright holder. To view a copy of this licence, visit http://creativecommons.org/licenses/by/4.0/.

\section{References}

Amato, P. R., Loomis, L. S., \& Booth, A. (1995). Parental divorce, marital conflict, and offspring well-being during early adulthood. Social Forces, 73(3), 895-915.

Andersen, L. H. (2016). How children's educational outcomes and criminality vary by duration and frequency of paternal incarceration. The Annals of the American Academy of Political and Social Science, 665(1), 149-170.

Bachman, R., \& Schutt, R. (2011). The practice of research in criminology and criminal justice. New York: Sage.

Beegle, K., Filmer, D., Stokes, A., \& Tiererova, L. (2010). Orphanhood and the living arrangements of children in sub-Saharan Africa. World Development, 38(12), 1727-1746.

Bernstein, N. (2005). All alone in the world: children of the incarcerated. New York: New Press.

Besemer, K. L., \& Dennison, S. M. (2018). Social exclusion in families affected by paternal imprisonment. Australian \& New Zealand Journal of Criminology, 51(2), 221-238.

Besemer, S., Van der Geest, V., Murray, J., Bijleveld, C. C., \& Farrington, D. P. (2011). The relationship between parental imprisonment and offspring offending in England and the Netherlands. The British Journal of Criminology, 51(2), 413-437.

Besemer, K. L., van de Weijer, S. G., \& Dennison, S. M. (2018). Risk marker or risk mechanism? The effect of family, household, and parental imprisonment on children and adults' social support and mental health. Criminal Justice and Behavior, 45(8), 1154-1173.

Braun, V., \& Clarke, V. (2006). Using thematic analysis in psychology. Qualitative Research in Psychology, 3(2), 77-101.

Butler, M. and Misinde, C. (2018). Primary Caregiver Imprisonment in Uganda: Its Impact on Child Poverty, Health and Education. Belfast: Queen's University Belfast.

Butler, M., Hayes, D., Devaney, J., \& Percy, A. (2015). Strengthening family relations? A review of the Families Matter Programme at Maghaberry prison. Belfast: Barnardo's NI.

Creswell, J. W. (2013). Research design: qualitative, quantitative, and mixed methods approaches. London: Sage Publications.

Dallaire, D. H. (2007). Incarcerated mothers and fathers: a comparison of risks for children and families. Family Relations, 56(5), 440-453.

Datzberger, S., \& Le Mat, M. L. (2018). Just add women and stir? Education, gender and peacebuilding in Uganda. International Journal of Educational Development, 59, 61-69.

Eddy, J. M., \& Reid, J. B. (2003). The adolescent children of incarcerated parents. In J. Travis \& M. Waul (Eds.), The impact of incarceration and re-entry on children, families and communities (pp. 233-258). Washington: Urban Institute.

Edwards, R., \& Holland, J. (2013). What is qualitative interviewing? London: Bloomsbury Publishing.

Farrington, D. (2003). Key results from the first forty years of the Cambridge study in delinquency. In T. P. Thornberry \& M. D. Krohn (Eds.), Taking stock of delinquency: an overview of findings from contemporary longitudinal studies (pp. 137-183). New York: Plenum.

Flynn, C., \& Eriksson, A. (2015). Children of prisoners. Annandale: The Federation Press.

Foster, H., \& Hagan, J. (2009). The mass incarceration of parents in America: issues of race/ethnicity, collateral damage to children, and prisoner reentry. The Annals of the American Academy of Political and Social Science, 623(1), 179-194.

Foundation for Human Rights Initiative. (2015). Human rights reform agenda: informing FHRI's New Advocacy Strategy. Kampala: Foundation for Human Rights Initiative.

Gaston, S. (2016). The long-term effects of parental incarceration: does parental incarceration in childhood or adolescence predict depressive symptoms in adulthood? Criminal Justice and Behavior, 43(8), 1056-1075.

Geller, A., Cooper, C. E., Garfinkel, I., Schwartz-Soicher, O., \& Mincy, R. B. (2012). Beyond absenteeism: father incarceration and child development. Demography, 49(1), 49-76.

Hagan, J., \& Dinovitzer, R. (1999). Collateral consequences of imprisonment for children, communities, and prisoners. Crime and Justice, 26, 121-162. 
Hagan, J., \& Foster, H. (2012). Intergenerational educational effects of mass imprisonment in America. Sociology of Education, 85(3), 259-286.

ICPR (2019). Highest to lowest world prison populations. Available at http://www.prisonstudies.org/highest-tolowest/prison-population-total (Accessed 28 June 2019).

Jones, A. D., \& Wainaina-Woźna, A. E. (2013). Children of prisoners: interventions and mitigations to strengthen mental health. Huddersfield: University of Huddersfield.

Kjellstrand, J. M., \& Eddy, J. M. (2011). Parental incarceration during childhood, family context, and youth problem behavior across adolescence. Journal of Offender Rehabilitation, 50(1), 18-36.

Lundgren, R., Burgess, S., Chantelois, H., Oregede, S., Kerner, B., \& Kågesten, A. E. (2019). Processing gender: lived experiences of reproducing and transforming gender norms over the life course of young people in Northern Uganda. Culture, Health \& Sexuality, 21(4), 387-403.

McCoy, D. C., Peet, E. D., Ezzati, M., Danaei, G., Black, M. M., Sudfeld, C. R., Fawzi, W., \& Fink, G. (2016). Early childhood developmental status in low-and middle-income countries: national, regional, and global prevalence estimates using predictive modeling. PLoS Medicine, 13(6), e1002034.

Mears, D. P., \& Siennick, S. E. (2016). Young adult outcomes and the life-course penalties of parental incarceration. Journal of Research in Crime and Delinquency, 53(1), 3-35.

Miller, H. V., \& Barnes, J. C. (2015). The association between parental incarceration and health, education, and economic outcomes in young adulthood. American Journal of Criminal Justice, 40(4), 765-784.

Murray, J. (2005). The effects of imprisonment on families and children of prisoners. In A. Liebling \& S. Maruna (Eds.), The effects of imprisonment (pp. 442-492). Cambridge: Cambridge University Press.

Murray, J., \& Farrington, D. P. (2008a). The effects of parental imprisonment on children. Crime and Justice, 37(1), 133-206.

Murray, J., \& Farrington, D. P. (2008b). Parental imprisonment: long-lasting effects on boys' internalizing problems through the life course. Development and Psychopathology, 20(1), 273-290.

Murray, J., Janson, C. G., \& Farrington, D. P. (2007). Crime in adult offspring of prisoners: a cross-national comparison of two longitudinal samples. Criminal Justice and Behavior, 34(1), 133-149.

Murray, J., Farrington, D. P., \& Sekol, I. (2012). Children's antisocial behavior, mental health, drug use, and educational performance after parental incarceration: a systematic review and meta-analysis. Psychological Bulletin, 138(2), 175-210.

Office of the Auditor General Uganda. (2016). Report of the Auditor General on the financial statement of Uganda Prisons Service for the financial year ended 30th June 2015. Kampala: Republic of Uganda.

Poehlmann, J. (2005). Representations of attachment relationships in children of incarcerated mothers. Child Development, 76, 679-696.

Republic of Uganda. (2007). Uganda Vision 2040. Kampala: Government of Uganda.

Republic of Uganda. (2015). Second National Development Action Plan (NPII) 2015/16-2019/20. Kampala: Government of Uganda.

Turney, K., \& Wildeman, C. (2015). Detrimental for some? Heterogeneous effects of maternal incarceration on child wellbeing. Criminology \& Public Policy, 14(1), 125-156.

Uganda Bureau of Statistics. (2015). Labour market transition of young people in Uganda. Kampala: Uganda Bureau of Statistics.

Uganda Bureau of Statistics. (2017). Uganda demographic and health survey 2016 key indicators report. Kampala: Uganda Bureau of Statistics.

UN. (2018). World economic situation and prospects. New York: United Nations.

UNCTAD. (2019). The least developed countries report 2019. New York: United Nations.

UNESCO (2019). Education finance. Available at: http://uis.unesco.org/en/topic/education-finance (Accessed: 7 December 2019).

UNICEF. (2016). Ending extreme poverty: a focus on children. New York: UNICEF.

Wakefield, S., \& Wildeman, C. (2013). Children of the prison boom: mass incarceration and the future of American inequality. Oxford: Oxford University Press.

Wildeman, C. (2014). Parental incarceration, child homelessness, and the invisible consequences of mass imprisonment. The Annals of the American Academy of Political and Social Science, 651(1), 74-96.

Wildeman, C., Goldman, A. W., \& Turney, K. (2018). Parental incarceration and child health in the United States. Epidemiologic Reviews, 40(1), 146-156.

World Bank (2019). Fertility rates, total (births per woman). Available at https://data.worldbank. org/indicator/sp.dyn.tfrt.in (Accessed: 18 November 2019).

World Population Review (2019). Countries with universal healthcare 2019. Available at http://worldpopulationreview.com/countries/countries-with-universal-healthcare/ (Accessed: 7 December 2019).

Publisher's Note Springer Nature remains neutral with regard to jurisdictional claims in published maps and institutional affiliations. 